in conservation of our natural resources is in its infancy, but the local committee is anxious that the project be presented to A.R.D.A. for action.

Certainly it is a multi-purpose project that would benefit agriculture, wildlife, water conservation, and recreation.

Certainly it would put much of the many natural resources of the area to better use.

It should benefit the Metis and the Indians, whose original reserve occupies part of the area.

It offers great benefits in recreational use.

It is unique in that it promises financial returns commensurate with the costs involved.

It is unique in that the necessary engineering and assessment have already been done.

The Dominion Director of A.R.D.A. is quoted in the Leader Post of February 7,1963 , as saying that in the early stages of their work a diversity of experimental projects is desired. The Yorkton Water Conservation and Development.. Project would seem an ideal project for implementation under A.R.D.A. It would benefit many thousands of our Saskatchewan citizens, and preserve for those who come after us a small and already rare example. of our natural heritage.

\title{
Pattern for a Refuge
}

\section{Montana's Charles M. Russell National Wildlife Range}

In these days when natural areas are disappearing, much attention is being focused on parks and refuges where government action has been taken to preserve the native character of the landscape. Sometimes these protected areas are both of his- toric interest and of value as a wildlife haven. Such is the case in the former Fort Peck Range in Montana, recently renamed the Charles $M$. Russell Wildlife Range in honour of Montana's noted naturalist-artist, who died in 1926.

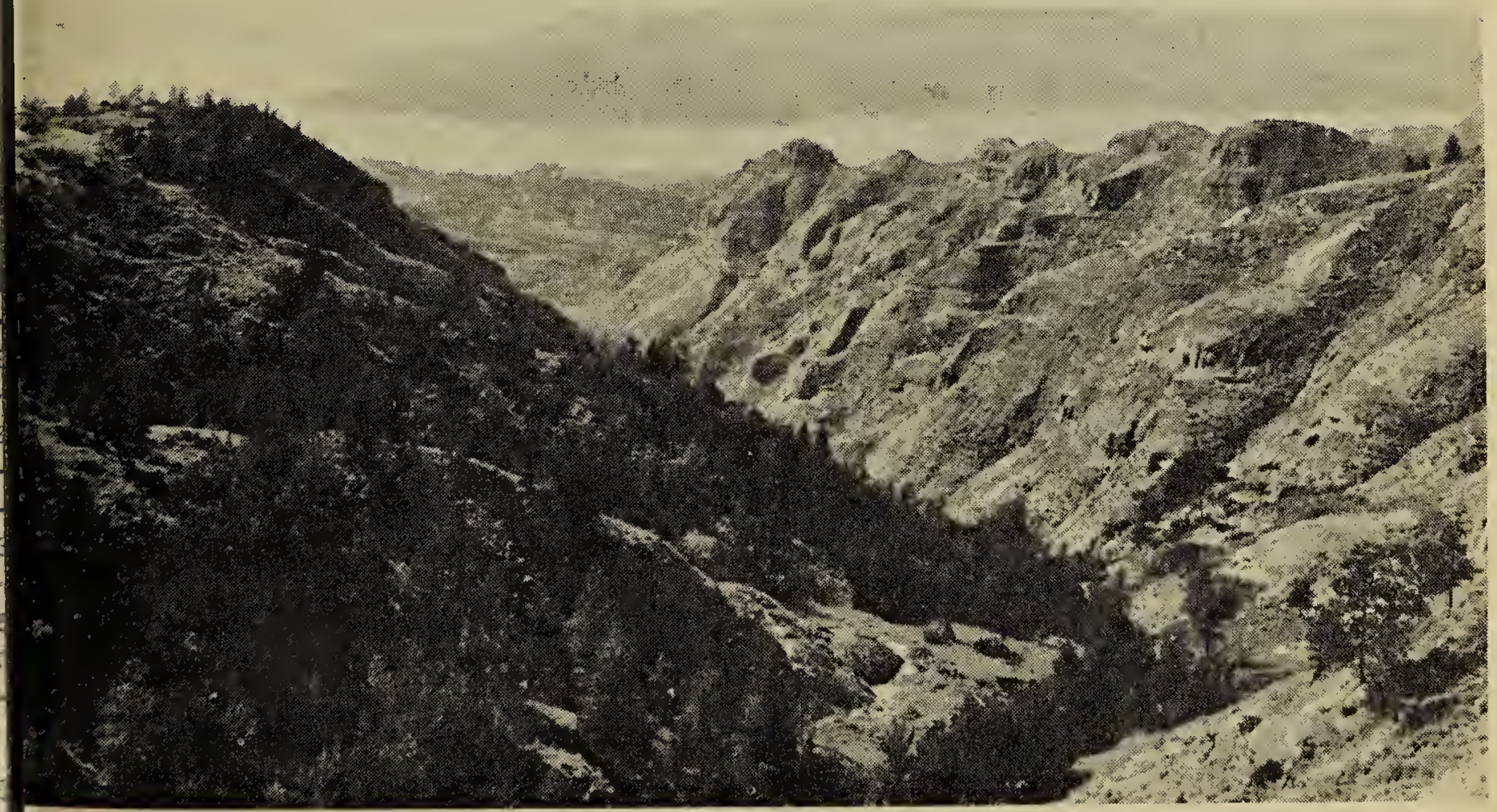

U.S. Department of the Interior Photo. iew of rugged badlands in the Charles M. Russell National Wildlife Range in north Garfield County, Montana. Fort Peck Reservoir in background. 


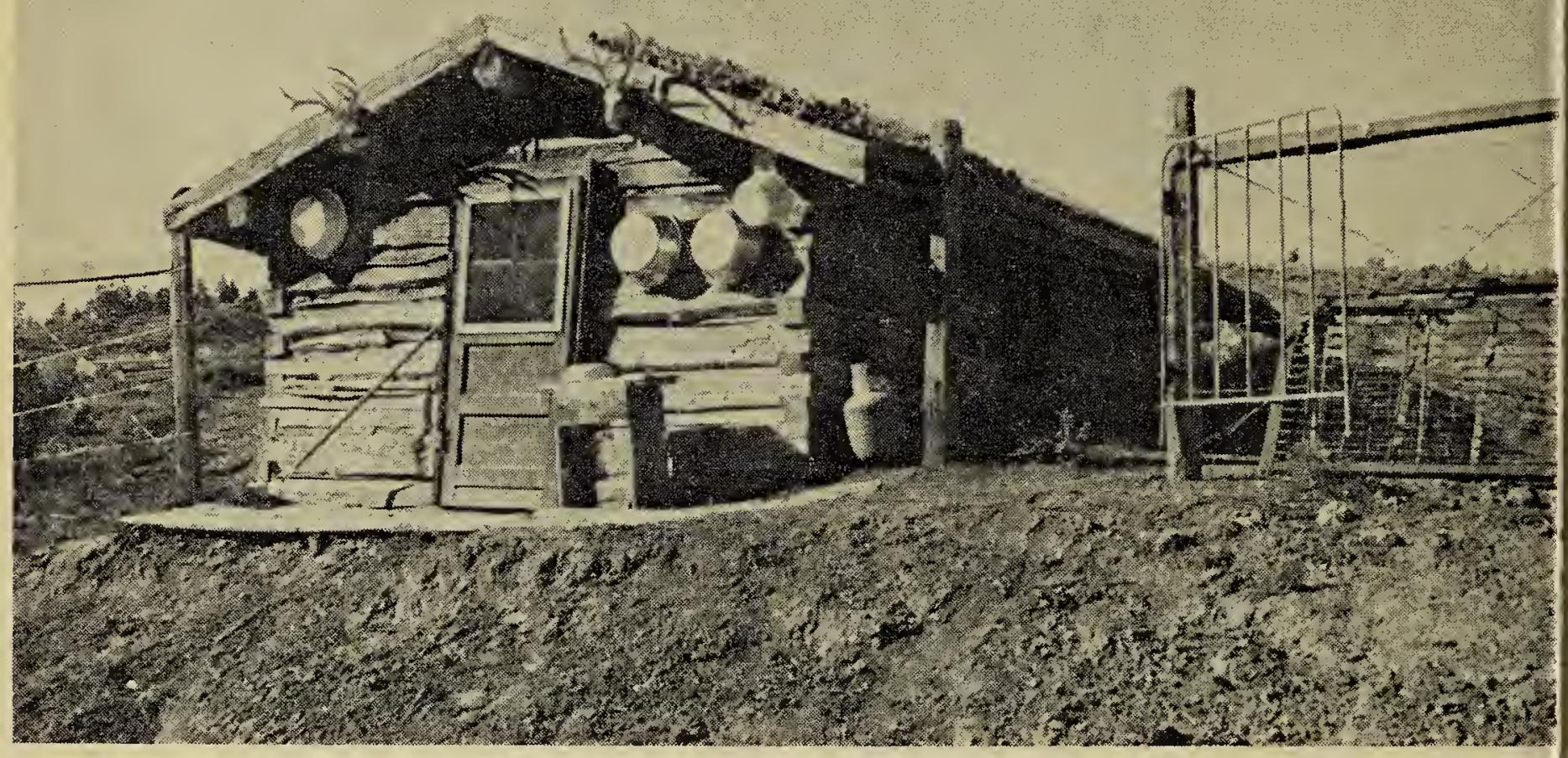

U.S. Department of Interior Photo.

The bunk house at Sipary Ann Game Station, which was developed from an old river ranch property. The bunk house is occupied both winter and summer.

One of the last natural stands of the great American buffalo, or bison, was in the "breaks" of Seven Mile Creek in this huge, half million acre wildlife refuge. Here the buffalo remained even after elk had disappeared from that part of Montana; only Audubon's mountain sheep outlasted the buffalo, maintaining a precarious existence in the "breaks" until 1900. Meanwhile, smaller animals and birds were brought clcse to destruction when the plow broke up the prairie habitat or when too many livestock moved in and took over the range. In the wooded bottomlands of the Missouri River, a few mule deer and white-tailed deer survived, and the population of these increased once more when the Fort Peck Game Range was established in 1936. Elk have been re-introduced, and the Rocky Mountain bighorn brought in to replace the original Audubon's mountain sheep. For three years the bighorn has thrived in fenced pastures and seems to be adapting itself to its new range under a cooperative program with the Montana Fish and Game Commission. Antelope still use this range, although it lacks sufficient depth to afford year-around habitat. They use the Wildlife Range as well as adjacent ranges, drifting on and off the area.
Canada Geese have been reestablished along the river and on the upper reaches of the Fort Peck Reservoir. During the past five years, the peak concentration observed during migration numbered 6,500, most of which were locally raised birds. With further development, this area cculd make a very substantial contribution to the waterfowl population of the Central Flyway.

Mourning Doves find the "breaks' to their liking and are stopping in increasing numbers because the planting of cereal grains on the river bottoms for waterfowl has developed a plentiful food supply. This area has become the greatest breeding ground west of the Mississipp River:

The mid-grass prairie type on the benchland was the home of severa birds and animals which are now precariously balanced on the edge of extinction. The Mountain Plover, Upland Plover, and Long-billed Curlew are becoming rarer. Prairie dog colonies will be permitted to remain here, along with their close associates, the Burrowing Owl and the very rare black-footed ferret. Balo Eagles and Golden Eagles frequent the "breaks" and badlands and finc suitable nesting sites in these inaccessible bluffs.-Digest of release from U.S. Fish and Wildlife Service 